\section{SUMMARY}

1. The colorimetric method for estimation of acetoacetate by reaction with diazotized $p$-nitroaniline has been adapted for measurements of oxaloacetate in amounts of $0.003-0.03 \mu$ mole.

2. The steady-state level of oxaloacetate in the livers of normal and fasted rats was found to be about $4 \mu \mathrm{moles} / 100 \mathrm{~g}$. dry wt. of tissue. The level was essentially unchanged in starvation when the level of acetoacetate increased tenfold.

The authors wish to thank Professor Sir Hans Krebs, F.R.S., and the members of the Medical Research Council Unit for their help, advice and interest during the progress of this work, and Mr T. Gascoyne for skilful technical assistance during the last stages of this work. One of us (G.K.) gratefully acknowledges the support of the Travelling Fellowship of the College of Medicine of the State University of Iowa, the National Science Foundation and Office of Naval Research (U.S.A.).

\section{REFERENCES}

Breusch, F. L. (1948). Advanc. Enzymol. 8, 408. Cantarow, A. \& Trumper, M. (1955). Clinical Biochemistry, p. 75. Philadelphia and London: W. B. Saunders.

Chaikoff, I. L. \& Brown, G. W. jun. (1954). In Chemical Pathways of Metabolism, vol. 1, p. 337. New York: Academic Press Inc.

Chernick, S. S. \& Chaikoff, I. L. (1951). J. biol. Chem. 188, 389.

Clark, G. W. (1953). A Vitamin Digest, p. 137. Springfield, Ill.: C. C. Thomas.

Deuel, H. J. jun., Hallman, L. \& Murray, S. (1937). Proc. Soc. exp. Biol., N.Y., 37, 413.
Frohman, C. E., Orten, J. M. \& Smith, A. H. (1951a). J. biol. Chem. 193, 277.

Frohman, C. E., Orten, J. M. \& Smith, A. H. (1951b). J. biol. Chem. 198, 803.

Hughes, D. E. (1951). Brit. J. exp. Path. 32, 97.

Krebs, H. A. (1942). Biochem. J. 36, 303.

Krebs, H. A. (1948-49). Harvey Lect. p. 165.

Krebs, H. A. \& Eggleston, L. V. (1945). Biochem. J. 89, 408.

Lawrence, R. D., McCance, R. A. \& Archer, N. (1937'. Brit. med. J. 2, 214.

Lehninger, A. L. (1946). J. biol. Chem. 164, 291.

Lynen, F. (1952-53). Harvey Lect. p. 229.

Lyon, I., Masri, M. S. \& Chaikoff, I. L. (1952). . J. biol. Chem. 196, 25.

Masoro, E. J., Chaikoff, I. L., Chernick, S. S. \& Felts, J. M. (1950). J. biol. Chem. 185, 845.

Medes, G., Spirtes, M. A. \& Weinhouse, S. (1953). J. biol. Chem. 205, 401.

Medes, G., Thomas, A. \& Weinhouse, S. (1952). J. biol. Chem. 197, 181.

Rabinowitz, J. C. \& Snell, E. E. (1947). Analyt. Chem. 19, 277.

Rabinowitz, J. C. \& Snell, E. E. (1948). J. biol. Chem. 176, 1157.

Siegel, L., Melnick, D. \& Oser, B. L. (1943). J. biol. Chem. $149,361$.

Terrell, A. W. (1938). Proc. Soc. exp. Biol., N.Y., 39, 300.

Walker, P. G. (1954). Biochem. J. 58, 699.

Weinhouse, S. \& Millington, R. H. (1951). J. biol. Chem. 193, 1.

West, E. S. \& Todd, W. R. (1955). Textbook of Biochemistry, p. 993. New York: Macmillan.

Wohl, A. \& Claussner, P. (1907). Ber. dtsch. chem. Ges. 40, 2308.

Wohl, A. \& Oesterlin, C. (1901). Ber. dtsch. chem. Ges, 34, 1139.

\title{
Oak-bark Tannins
}

\author{
By D. E. HATHWAY \\ The British Leather Manufacturers' Research Association, Milton Park, Egham, Surrey
}

(Received 14 January 1958)

The barks of the two common oaks, the pedunculate oak (Quercus pedunculata Ehrh.) and the sessile oak (Quercus sessiliflora Salisb.) have been the traditional tanning material of Britain and northern Germany since medieval times. The principal botanical difference between the species is that the pedunculate oak has acorns on a long peduncle and stalkless or nearly stalkless leaves, whereas the sessile oak has sessile or stalkless acorns and petiolated leaves, but intermediate or hybrid forms are common. For commercial purposes, the timber and bark of these trees are not differentiated. Our experience of this tanning material shows that best-quality oak bark contains
$12-16 \%$ of tannin [cf. Howes (1953) who gives $12-14 \%]$.

Little information on oak-bark phlobatannins is available, but $(+)$-catechin and $(+)$-gallocatechin have recently been isolated from this source (Mayer, 1956; cf. Casparis \& Reber, 1929). The nature of the partial-type formula for oak-bark phlobatannins has now been investigated. Phlobatannins have recently been isolated in high yield from the extractives of Acacia catechu heartwood and harvested Uncaria gambir leaves (Hathway \& Seakins, 1957a), which have the same analytical properties and similar elementary analyses and absorption spectra to those of the polymers of 
catechin oxidation (Hathway \& Seakins, 1955; $1957 b$; Hathway, 1958). There is therefore a strong supposition that these phlobatannins are formed by aerobic oxidation of catechin epimers by polyphenoloxidases in the heartwood and detached leaves respectively (Hathway \& Seakins, 1957a). The isolation of the free plant phenolics and the purification of a phlobatannin fraction from oak bark, and an investigation of the polyphenoloxidase activity of the cambium, have been undertaken. The phenolics of mature leaves and the distribution of tannin extractives in stembark have also been explored.

\section{EXPERIMENTAL}

General. Evaporations were carried out in $\mathrm{N}_{2}$ under reduced pressure at a temperature below $35^{\circ}$. Paper chromatography was carried out in all-glass apparatus in a constant-temperature enclosure at $25^{\circ}$. Chromatograms were dried at room temperature, unless otherwise stated. Melting points were determined on a Kofler block. Specific rotations were determined for the $\mathrm{D}$ line of sodium, with a $1 \mathrm{dm}$. microtube. Five pairs of readings with the solutions and five pairs. with a solvent blank were taken in each case, at $20-25^{\circ}$.

\section{Systematic separation of an $80 \%$ methanolic extract of oak bark into fractions of chemically similar} substances

Slivers of stembark were stripped from a 20-year-old oak sapling immediately after felling. A portion was used for the analysis of moisture, and of tannin and non-tannin extractives (Official Methods of Analysis, 1957). Acids and salts were estimated by titration with $0.02 \mathrm{~N}-\mathrm{NaOH}$ on portions withdrawn from such an aqueous extract as that required by the Official Methods, before and after its passage through a Zeo-Karb 225 cation-exchange resin (2 mg.equiv.) ml.) in the $\mathrm{H}^{+}$cycle. The stembark, which had a $60 \%$ moisture content, contained $12.6 \%$ of tannin and $6.9 \%$ of non-tannin extractives on the moisture-free bark. Each $100 \mathrm{~g}$. of extractives contained $60 \mathrm{mg}$.equiv. of acid and $70 \mathrm{mg}$.equiv. of salt.

A portion (500 g.) of fresh bark was percolated with methanol (1.51.) for 5 days, after which the cell-wall fraction was removed by filtration through a sintered-glass funnel, and pressed and washed $(5 \times 100 \mathrm{ml}$.) with $80 \%$ methanol. Partial evaporation of the combined filtrate and washings left a soln. (400 ml.) which was continuously extracted for 4 days with peroxide-free ether in a Schacherl apparatus, ice-water being pumped through the condenser. Evaporation of the solvent left a solid residue which was dried over $\mathrm{P}_{2} \mathrm{O}_{5}$ at $20^{\circ}$ in vacuo for 2 days. The ethersoluble fraction $(4 \cdot 3 \mathrm{~g}$.) constituted $2.2 \%$ by wt. of the moisture-free bark.

Residual ether was removed from the aqueous phase, which was continuously extracted for $200 \mathrm{hr}$. with four changes of ethyl acetate in a Schacherl apparatus. Evaporation of the solvent left solid residues $(5 \mathrm{~g}$.) which constituted $2.5 \%$ by wt. of the moisture-free bark.

Residual ethyl acetate was removed from the aqueous phase, which was then percolated $(40 \mathrm{ml} . / \mathrm{hr}$.) through a column (bed-volume, $20 \mathrm{ml}$.) of Zeo-Karb 225 cationexchange resin ( $1.95 \mathrm{mg}$.equiv. $/ \mathrm{ml}$.) in the $\mathrm{H}^{+}$cycle, which was washed free from acid. The total effluent $(800 \mathrm{ml}$.) was evaporated to $500 \mathrm{ml}$., when a trace of insoluble material was removed by filtration through a few centimetres of Celite no. 535 (Johns-Manville Inc.) on a sintered-glass funnel. The filtrate contained $10 \%$ of tannin (hide-powder test).

\section{Paper chromatography of the ether-, ethyl acetate- and water-soluble phenolics}

A $2 \%$ methanolic solution of the fraction under investigation was spotted $(5 \mu \mathrm{l}$.) at a distance of $2 \mathrm{~cm}$. from both edges of the lower left-hand corners of Whatman no. 2 filter papers, $25.5 \mathrm{~cm}$. square, and chromatographed by the ascending method with $3 \%(v / v)$ acetic acid containing $2 \%$ $(v / v)$ formic acid as first-way solvent system. The solvent was irrigated to within $1 \mathrm{~cm}$. of the upper edge of the paper, which was subsequently dried, and developed in the other dimension with butan-2-ol-acetic acid-water (14:1:5, by vol.) for $20 \mathrm{hr}$. With the water-soluble phenolics, $50 \%$ (v/v) acetic acid was used as the second-way solvent system. Phenolics were detected by dipping the papers in a $1: 1$ (v/v) mixture of $0.3 \% \mathrm{FeCl}_{3}$ and $0.3 \% \mathrm{~K}_{3} \mathrm{Fe}(\mathrm{CN})_{6}$ solutions, and by means of a spraying reagent consisting of a mixture of 1 vol. of $12 \mathrm{~N}-\mathrm{HCl}$ with 2 vol. of a $10 \%(w / v)$ solution of vanillin in ethanol.

\section{Separation of the ether-and ethyl acetate-soluble} phenolics by partition chromatography on silica gel

Chromatographic grade silica gel (100 g., mesh size 100-200; L. Light and Co. Ltd.) was stirred with two 1 l. portions of $2 \mathrm{~N}-\mathrm{HCl}$ at $100^{\circ}$ for $2 \mathrm{hr}$; 估e supernatant was then decanted, and the sediment washed free from acid to Congo red. The wet slurry was washed with 21 . of methanol, air-dried and reactivated at $110^{\circ}$ for $8 \mathrm{hr}$.

Suitable tubes were packed with the silica gel $(80 \mathrm{~g}$. which had been triturated with water $(52 \mathrm{ml}$.) and slurried with peroxide-free ether by Bradfield, Penney \& Wright's (1947) method. The eluent was prepared by equilibration of peroxide-free ether with excess of water, followed by retention of the upper phase. The orange powder from the ether extraction $(4 \cdot 3 \mathrm{~g}$.) was triturated with portions of wet ether (total, $100 \mathrm{ml}$.), and the solution decanted from insoluble material (500 mg.) was applied to the top of the column, which was subsequently percolated $(2 \mathrm{ml} . / \mathrm{min}$.) with wet ether.

With the ethyl acetate-soluble phenolics, the column was packed with silica gel which had been triturated with the same proportion of water and slurried with ethyl acetate. The cream powder (3.5 g.), corresponding to the first two fractions in Table 2, was applied to the top of the column, which was eluted with wet ethyl acetate.

\section{Isolation of leucodelphinidin}

The first $100 \mathrm{ml}$. of eluate obtained from the column on which the ethyl acetate-soluble phenols were adsorbed contained an unresolved mixture of phenolics (2 g.). Evaporation of the next $200 \mathrm{ml}$. of eluate left $1 \mathrm{~g}$. of leucodelphinidin, which separated in crystals, m.p. 155$160^{\circ}, R_{F} 0.4$ in butan-2-ol-acetic acid-water (14:1:5, by vol.) (Found: $\mathrm{C}, 53 \cdot 0 ; \mathrm{H}, 5 \cdot 1$. $\mathrm{C}_{15} \mathrm{H}_{14} \mathrm{O}_{8}, \mathrm{H}_{2} \mathrm{O}$ requires $\mathrm{C}$, $53.0 ; \mathrm{H}, 4.7 \%$ ) which afford delphinidin on treatment with acid. The hepta-acetate melted at $140-144^{\circ}$ (Found: C, 56.5; $\mathrm{H}, 5 \cdot 2$. $\mathrm{C}_{29} \mathrm{H}_{35} \mathrm{O}_{15}$ requires $\mathrm{C}, 56 \cdot 0 ; \mathrm{H}, 5 \cdot 6 \%$ ). 


\section{Investigation of the ethyl acetate-soluble fraction for leucoanthocyanins}

A portion $(20 \mathrm{mg}$.) of each ethyl acetate-soluble fraction and one broad-bean (Vicia faba) testa were treated with $3 \mathrm{ml}$. of $2 \mathrm{~N}-\mathrm{HCl}$ at $100^{\circ}$ for $20 \mathrm{~min}$., and the supernatant was decanted into a narrow test tube and extracted with enough $n$-amyl alcohol to give an upper phase of sufficient depth for spotting on starting lines, $3 \mathrm{~cm}$. from the lower edges of Whatman filter paper no. $1,57 \mathrm{~cm}$. in length. The applications were repeated with intermittent drying, until the colour of each spot was intense enough to ensure visibility of the anthocyanidins on the developed chromatograms. Single-way ascending chromatography was effected with water-acetic acid-12 N-HCl $(10: 30: 3$, by vol. $)$, and $m$-cresol-5.5 $\mathrm{N}-\mathrm{HCl}$-acetic acid (1:1:1, by vol.) solvent systems (Bate-Smith, 1954).

\section{Purification of the phlobatannin fraction by cellulose-column chromatography}

Solka Floc cellulose (Grade, BW 200) (Johnsen, Jörgensen, and Wettre Ltd., Wood Pulp Agents, 26, Farringdon St., London, E.C. 4) was stirred twice with large portions of $2 \mathrm{~N}-\mathrm{HCl}$ and washed free from acid to Congo red on a sintered-glass filter. The iron-free pulp was washed with methanol, air-dried and homogenized in acetone by a topdrive macerator, and the slurry was transferred to a chromatography tube made out of Pyrex pipe-line components. The column $(60 \mathrm{~cm} . \times 5 \mathrm{~cm}$.) was developed with acetone, and stored for $48 \mathrm{hr}$. and developed under pressure with aq. $10 \%(\mathrm{v} / \mathrm{v})$ formic acid until free from acetone. A volume (125 ml.) of the aqueous solution containing the water-soluble phenolics was applied to the top of the column, from which the sugars and mobile phenolics were eluted with $5 \mathrm{l}$. of $10 \%(\mathrm{v} / \mathrm{v})$ formic acid. Oak-bark phlobatannin occupied a zone stretching from 2.5 to $\mathbf{7 . 5} \mathrm{cm}$. from the top of the column.

\section{Fractionation of an $80 \%$ methanolic extract of oak leaves}

Mature sun-leaves (80 g.), harvested in August, were plunged into ice-cold $80 \%$ methanol $(500 \mathrm{ml}$.) and homogenized in a top-drive macerator for $5 \mathrm{~min}$. The homogenate was filtered through sintered glass, and the filtrate was extracted with successive portions of light petroleum (b.p. $40-60^{\circ}$ ) until free from chlorophyll and related compounds. Partial evaporation of the lower phase afforded an aqueous solution which was successively extracted with ether and ethyl acetate. The ether-soluble fraction accounted for $0.25 \%$ (by wt.) of the leaves, and the ethyl acetate-soluble fraction for a further $0.5 \%$. The extracts were examined for phenolics by conventional two-dimensional paper chromatography.

Isolation of (-)-epicatechin from Acacia catechu heartwood. Chips (100 g.) of Acacia catechu heartwood, extracted with acetone by the method of Rao \& Seshadri (1948), afforded (-)-epicatechin (1 g.) which crystallized from water, forming needles, m.p. $243-244^{\circ},[\alpha]_{D}-69^{\circ}$ (c, 1; ethanol).

Epigallocatechin. A specimen was made available for the purpose of chromatographic identification through the courtesy of Dr E. A. H. Roberts, of the Indian Tea Association, London, S.E. 1.
Acetone-dried powder of oak cambium. A 20-year-old sapling was felled, and the stembark was immediately peeled. Cambium detached from the freshly exposed surfaces of the bark and sapwood was plunged into 21 . of acetone at below $0^{\circ}$, and sliced, and homogenized in a topdrive macerator. The homogenate obtained was filtered through sintered glass, and the solid $(20 \mathrm{~g}$.) was immediately washed five times with $500 \mathrm{ml}$. portions of ice-cold acetone and dried over paraffin wax at $0^{\circ}$ in vacuo. The crude preparation had a polyphenoloxidase activity of purpurogallin number (P.N.) of 0.003. P.N. represents milligrams of purpurogallin formed from pyrogallol in $5 \mathrm{~min}$. at $20^{\circ} / \mathrm{mg}$. dry wt. of enzyme preparation. A Hilger Uvispek spectrophotometer was used for the P.N. determination by Keilin \& Mann's (1938) method. This preparation was ground in a chilled Wiley mill, and homogenized five times with $500 \mathrm{ml}$. portions of ice-cold acetone, and filtered and dried over paraffin wax at $0^{\circ}$ in vacuo. Wood fibres were removed. This powder ( 0.09 enzyme unit) had a P.N. of 0.005. One enzyme unit (E.J.) corresponds to the quantity of enzyme which produces $1 \mathrm{~g}$. of purpurogallin in $5 \mathrm{~min}$. at $20^{\circ}$.

Manometry. Use was made of Haldane's (1921) constantpressure respirometer (Hathway \& Seakins, 1957a). Both the reaction and the compensation vessels were shaken at $30 \pm 0.05^{\circ}$ at a speed sufficient to maintain the reaction mixture as a foam.

5-Methoxy-4-methylresorcinol. A specimen, m.p. $120^{\circ}$ (Found: $\mathrm{C}, 62 \cdot 1 ; \mathrm{H}, 6 \cdot 7$. Calc. for $\mathrm{C}_{8} \mathrm{H}_{10} \mathrm{O}_{3}: \mathrm{C}, 62.4 ; \mathrm{H}$, $6.5 \%$ ), was prepared by the method of Robertson \& Whalley (1951).

4-Nitrocatechol. A specimen, m.p. 174-175 ${ }^{\circ}$ (decomp.), was prepared from $o$-dibenzyloxybenzene by the method of Burton \& Praill (1951).

\section{Synthesis of 5-methylpyrogallol}

Orcyl aldehyde (I), m.p. $180^{\circ}$ (Adams \& Levine, 1923), was converted into the dicarbomethoxy derivative (II), m.p. 84-85 methoxyorsellinic acid (III), m.p. 132-134 ${ }^{\circ}$, by the method of Hoesch (1913). Purdie methylation of III, followed by partial hydrolysis by the method of Robertson \& Stephenson (1932), gave methyl orsellinate (IV), which crystallized from dilute methanol, forming prisms, m.p. $142^{\circ}$.

Preparation of methyl haematommate (V). Powdered, anhydrous $\mathrm{ZnCl}_{2}$ was suspended in an ether soln. (300 ml.) of methyl orsellinate $\left(7 \cdot 1 \mathrm{~g}\right.$.) $; \mathrm{Zn}(\mathrm{CN})_{2}(11 \mathrm{~g}$.) was added and $\mathrm{HCl}$ gas was conducted through the reaction mixture at $0^{\circ}$ for $4 \mathrm{hr}$. The mother liquor was decanted from the crystalline aldimine hydrochlorides, which were washed four times with $100 \mathrm{ml}$. portions of absolute ether. The aldimine hydrochlorides were dissolved in $100 \mathrm{ml}$. of water and the soln. was heated at $100^{\circ}$ for $\mathbf{4 0} \mathrm{min}$. After cooling for $16 \mathrm{hr}$., the product was collected and steam-distilled. Almost pure methyl haematommate (V) (3.1 g., $38 \%$ yield) separated from $5 \mathrm{l}$. of distillate at $0^{\circ}$, and crystallized from $100 \mathrm{ml}$. of methanol, forming glistening needles, m.p. $147^{\circ}$ (Found: C, 57.1; $\mathrm{H}, 4.8$. Calc. for $\mathrm{C}_{10} \mathrm{H}_{10} \mathrm{O}_{5}: \mathrm{C}, 57 \cdot 1 ; \mathrm{H}$, $4.8 \%$ ), which were dried over $\mathrm{P}_{2} \mathrm{O}_{5}$ at $65^{\circ}$ in vacuo. The non-volatile solid which separated from the residual liquor after steam-distillation, crystallized from water (charcoal), forming parallelepipeds, m.p. $130^{\circ}$ (Found: C, $57.0 ; \mathrm{H}, 4.6)$, of methyl isohaematommate, in $4 \%$ yield. Repetition of this preparation, with $\mathrm{BF}_{3}$-ether complex 
<smiles>[R20]c1cc(C)c(O)c(C(C)=O)c1</smiles>

(I, R= H; $\mathrm{R}^{\prime}=\mathrm{CHO}$ )

(II, $\mathrm{R}=\mathrm{CO}_{2} \mathrm{Me} ; \mathrm{R}^{\prime}=\mathrm{CHO}$ )

(III, $\mathrm{R}=\mathrm{CO}_{2} \mathrm{Me} ; \mathrm{R}^{\prime}=\mathrm{CO}_{2} \mathrm{H}$ )

(IV, $\mathrm{R}=\mathrm{H} ; \mathrm{R}^{\prime}=\mathrm{CO}_{\mathbf{8}} \mathrm{Me}$ )
(V)

$$
\text { (VI, } \mathrm{R}=\mathrm{CHO} \text { ) }
$$

(VII, $\mathbf{R}=\mathbf{O H}$ )

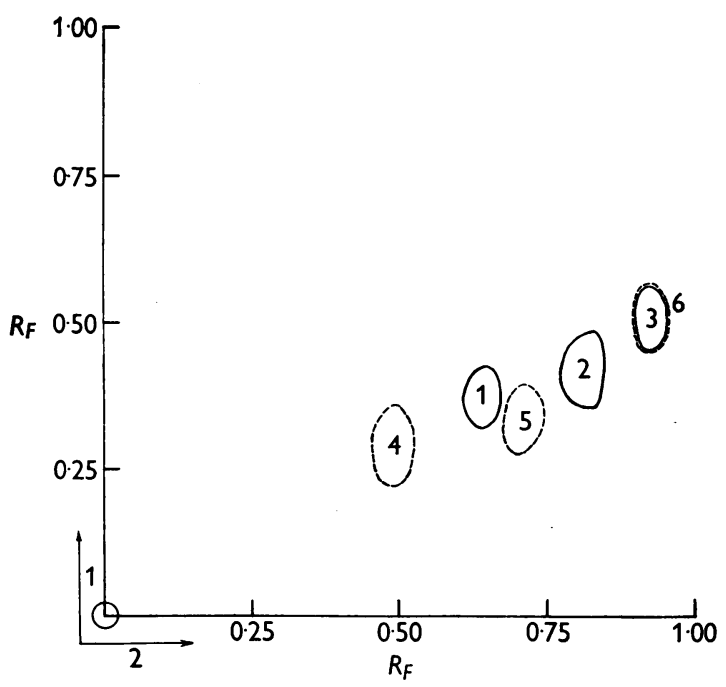

Fig. 1. Two-dimensional chromatogram of the ethersoluble phenolics. The material was applied in the position marked $\odot$ and run first in $6 \%(v / v)$ acetic acid containing $2 \%(\nabla / v)$ of formic acid, followed by butan2-ol-acetic acid-water (14:1:5, by vol.). Spots located by $\mathrm{FeCl}_{3}-\mathrm{K}_{3} \mathrm{Fe}(\mathrm{CN})_{6}:$ 1, (+)-gallocatechin; 2, (+)catechin; 3, unknown; 4, epigallocatechin; 5, epicatechin; 6 , methyl gallate.

(1 ml.) (Eastman Kodak Co., Rochester, U.S.A.) gave a $45 \%$ yield of methyl haematommate. Both preparations are improved variations of Curd, Robertson \& Stephenson's (1933) preparation.

Hydrolysis of methyl haematommate gave atranol (VI), which crystallized from benzene in the form of paleyellow needles, m.p. $124^{\circ}$, which were converted by the Dakin reaction into 5-methylpyrogallol (VII) by the method of Pfau (1926). 5-Methylpyrogallol crystallized from benzene, and sublimed at $105^{\circ} / 0.01 \mathrm{~mm}$. $\mathrm{Hg}$, forming long needles, m.p. $119^{\circ}$ (Found: C, 60.1; H, 5.5. Calc. for $\mathrm{C}_{7} \mathrm{H}_{8} \mathrm{O}_{3}: \mathrm{C}, 60 \cdot 0 ; \mathrm{H}, 5 \cdot 8 \%$ ), which were dried over $\mathrm{P}_{2} \mathrm{O}_{6}$ at $65^{\circ}$ in vacuo.

In the aerobic oxidation experiments, $0.1 \mathrm{~m}$-mole of 5-methylpyrogallol, and mixtures of $0.1 \mathrm{~m}$-mole of this substance and $0.1 \mathrm{~m}$-mole of phloroglucinol or 5-methoxy4-methylresorcinol, underwent auto-oxidation at $30 \pm 0.05^{\circ}$, in $20 \mathrm{ml}$. of phosphate buffer, pH 7, for 2 days. Similar enzymic experiments were carried out in $3 \mathrm{hr}$.

\section{RESULTS}

The present work consists of a study in vitro of the aerobic oxidation of the $(+)$-gallocatechin and leucodelphinidin metabolites by oak-cambium polyphenoloxidase to a polymer comparable with the phlobatannin, which has now been isolated in $2 \%$ yield from the bark.

Young oak bark contains 50-60\% of moisture and extractable 'tannins' account for about $12 \%$ of the dry bark. The bark was extracted with $80 \%$ methanol, the solvent removed and the phenolics and tannins in the resulting aqueous solution were fractionated by solvent extraction.

A two-dimensional chromatogram of the ethersoluble phenolics showed the presence of three constituents (Fig. 1). Two of these metabolites were chromatographically indistinguishable from catechin and gallocatechin respectively, and both compounds gave the vanillin reaction. The absence of epicatechin and epigallocatechin was shown by the use of the authentic substances as markers. The third component did not react with vanillin, and was indistinguishable from methyl gallate on the chromatogram.

The ether-soluble phenolics were separated by partition chromatography on silica gel, with wet ether as eluent (Table 1). (+)-Catechin and (t)gallocatechin were isolated from well-separated bands, and the physical properties and elementary analyses of these substances were in excellent agreement with previous findings (Freudenberg \& Purrmann, 1924; Mayer, 1956). No crystalline material was obtained from the first band, however, which showed that the most mobile constituent was not methyl gallate.

The ethyl acetate-soluble phenolics were further fractionated on a time basis (Table 2). Twodimensional chromatograms (Fig. 2) showed that the first two fractions contained three vanillinpositive constituents which were of lower $R_{F}$ values in the second-way solvent system than those of the ether-soluble phenolics. All four fractions on treatment with warm acid generated mixtures of anthocyanidins, which were identified by single- 
Table 1. Separation of the ether-soluble phenolics by partition chromatography on silica gel

Total recovery was $3.75 \mathrm{~g}$. from an ether-soluble fraction weighing $3.8 \mathrm{~g}$. A narrow pink band 1.0-1.5 cm. from the top of the column, and a yellow band somewhat lower were not investigated
Description of band
1. Greenish brown
Eluate
(ml.)
60

2. Pink

Absence of bands

3. Yellow
500

200

500
Phenolics recovered from eluates

Oily residue $\left(750 \mathrm{mg}\right.$.) contained the phenolic, $R_{F} 0.95$ in butan-2-ol-acetic acid-water, but no crystalline material was obtained

(+)-Catechin (1.7 g.) crystallized from hot water $(8 \mathrm{ml}$. forming needles, m.p. and mixed m.p. 173-175,$[\alpha]_{\mathrm{p}}+8^{\circ}$ (c, 1 ; acetone) (Found: C, 50.0; H, 5.8. Calc. for $\mathrm{C}_{15} \mathrm{H}_{14} \mathrm{O}_{6}$, $4 \mathrm{H}_{2} \mathrm{O}: \mathrm{C}, 49 \cdot 8 ; \mathrm{H}, 6 \cdot 1 \%$ )

(+)-Gallocatechin (1.3 g.) crystallized from hot water (8 ml.), forming needles, m.p. $189-191^{\circ},[\alpha]_{\mathrm{p}}+15^{\circ}[c, 1 ; 50 \%(\mathrm{v} / \mathrm{v})$ acetone] (Found: C, 52.7; $\mathrm{H}, 5 \cdot 6$. Calc. for $\mathrm{C}_{15} \mathrm{H}_{14} \mathrm{O}_{7}, 2 \mathrm{H}_{2} \mathrm{O}$ : $\mathrm{C}, 52 \cdot 7 ; \mathrm{H}, 5 \cdot 3 \%$ )

Table 2. Ethyl acetate extraction of the aqueous extract

$\left.\begin{array}{ccc}\text { Fraction } & \begin{array}{c}\text { Extraction } \\ \text { (hr.) }\end{array} & \begin{array}{c}\text { Residue } \\ \text { (g.) }\end{array} \\ 1 & 75 & 2 \cdot 8 \\ 2 & 25 & 0.7 \\ 3 & 25 & 0.5 \\ 4 & 75 & 1.0\end{array}\right\}$

Examination of the residue by paper chromatography

Total 200

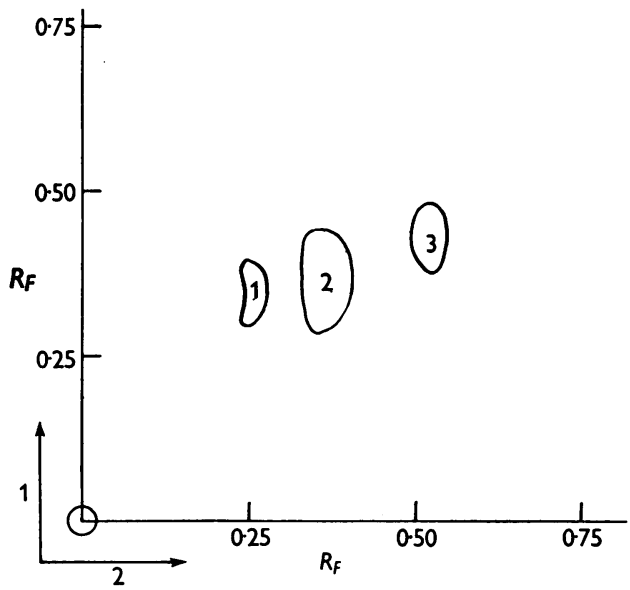

Fig. 2. Two-dimensional chromatogram of the ethyl acetate-soluble phenolics, the same solvent systems being used as in Fig. 1. Spots located by vanillin: 1, unknown; 2, leucodelphinidin; 3, unknown.

way paper chromatography in two different solvent systems as cyanidin and delphinidin (Bate-Smith, 1954), and the location of the absorption bands of these pigments on paper agreed with the recorded wavelengths. At least two of the constituents (Fig. 2) are therefore leucoanthocyanins, which also have the same hydroxylation pattern as the related cyanidin and delphinidin. The chromatogram in Fig. 2 shows that one constituent pre- dominates in the first two fractions. This major constituent should therefore be capable of purification by partition chromatography. Despite the fact that the first band contained all three phenolics, crystalline leucodelphinidin was isolated from the second band, which was eluted from a silica gel column with wet ethyl acetate. This compound, which was characterized by a hepta-acetate derivative, gave delphinidin on treatment with acid. (+)-Catechin accounts for $1 \%$ of the dry weight of young oak bark, (+)-gallocatechin for up to $1 \%$ and leucodelphinidin for approximately $0.5 \%$.

A two-dimensional chromatogram of the cationfree water-soluble extractives run first in $\mathrm{N}$-acetic acid containing $2 \%(\mathrm{v} / \mathrm{v})$ of formic acid, followed by $50 \%(v / v)$ acetic acid, revealed the presence of mobile, vanillin-positive phenolics, in addition to the phlobatannin which remained at the origin. The extract also contained free sugars. A portion of the extract was therefore adsorbed on the top of a large cellulose column, which was then eluted with $10 \%$ formic acid to remove contaminating sugars and mobile phenolics. The chemical nature of mixtures of phenolics present in fractions of effluent is described in Table 3. Since the anthocyanidins generated from these fractions by treatment with acid were separated as round spots on a paper chromatogram, it is unlikely that the corresponding leucoanthocyanins are polymeric. These leucoanthocyanins are probably glycosides. 
Table 3. Purification of the phlobatannin fraction by cellulose-column chromatography

Vol. of

eluate (1.) Examination of mixed products

0.6-1.4 Sugar extractives (anthrone reagent)

1.0-1.4 Vanillin-positive phenolic, $R_{F} 0.72$ in $6 \%$ $(\nabla / \nabla)$ acetic acid containing $2 \%(\nabla / v)$ of formic acid, affords cyanidin by acid treatment

1.5-1.7 Vanillin-positive phenolic, $R_{F} 0.64$ in the same solvent system, affords cyanidin and delphinidin by acid treatment

1.8-2.9 Vanillin-positive phenolic, $R_{F} 0.52$ in the same solvent system, gives mostly delphinidin on acid treatment

3-5 Vanillin-positive phenolic, $R_{F} \mathbf{0 . 3}$ in this solvent system, gives mostly delphinidin on acid treatment

Phlobatannin (1 g.) of low $R_{F}$ was eluted

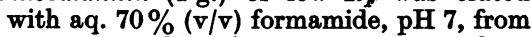
a zone stretching from 2.5 to $7.5 \mathrm{~cm}$. from the top of the column. The eluate, $\lambda_{\max }$. $285 \mathrm{~m} \mu$, was evaporated in vacuo, and the residue (Found: $\mathrm{C}, 53 \cdot 3 ; \mathrm{H}, 5 \cdot 1 . \mathrm{C}_{15} \mathrm{H}_{10} \mathrm{O}_{2}$, $2 \mathrm{H}_{2} \mathrm{O}$ requires $\mathrm{C}, 53 \cdot 3 ; \mathrm{H}, 4 \cdot 2 \%$ ), which was washed with water and dried at $65^{\circ}$ in vacuo, gave a vanillin reaction

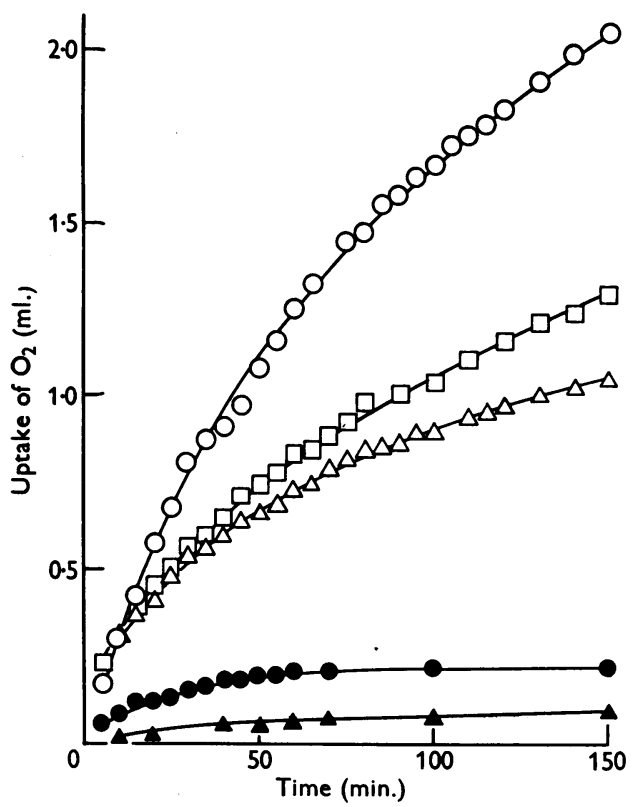

Fig. 3. Progress curves for the oxidation of gallocatechin, catechin and leucodelphinidin by oak-cambium polyphenoloxidase. In addition to $20 \mathrm{ml}$. of $0.07 \mathrm{M}$-phosphate buffer, pH 7, and $5 \times 10^{-4} \mathrm{k} . \mathrm{U}$. of oak-cambium polyphenoloxidase (O), the reaction flask contained $0.1 \mathrm{~m}$-mole of gallocatechin $(O)$; catechin $(\Delta)$; leucodelphinidin ( $\square$ ); or $0.1 \mathrm{~m}$-mole of catechin and $1 \mathrm{~m}$-mole of 4-nitrocatechol (A). A compensatory flask contained phosphate buffer.
The top zone of the column was eluted with $70 \%$ formamide (Hathway, 1956a). This eluate showed intense absorption at $285 \mathrm{~m} \mu$ (Fig. 4) and, on evaporation, the phlobatannin, which accounted for $2 \%$ of the dry weight of young bark, analysed for $\mathrm{C}_{15} \mathrm{H}_{10} \mathrm{O}_{7}, 2 \mathrm{H}_{2} \mathrm{O}$.

A methanolic extract derived from mature sun leaves was fractionated in the same way as the bark. Catechin and gallocatechin were identified in the ether-soluble fraction, and the three vanillinpositive phenolics in the ethyl acetate-soluble fraction. Besides these compounds some plant pigments, including quercetin, were present.

An acetone-dried powder of oak cambium which was substantially free from phenolics, had marked polyphenoloxidase activity. The crude enzyme preparation was tested with (+)-gallocatechin in phosphate buffer at $30^{\circ}$ and $\mathrm{pH} 7$, and the aerobic oxidation of this substance went smoothly to completion. At the level of enzyme concentration used, the rate of uptake of oxygen diminished very slowly during the course of reaction with this substrate. Such progress curves contrast with those for the aerobic oxidation of $(+)$-catechin by mushroom, potato and tobacco polyphenoloxidases (Hathway \& Seakins, 1957a), as they show less enzyme inactivation. The enzyme concentrations in the present work were smaller than the previous ones, and these results suggest that the cambium enzyme is particularly suited to the oxidation of $(+)$-gallocatechin. Progress curves for the aerobic oxidation of $(+)$-catechin, (+)-gallocatechin and leucodelphinidin at the same enzyme concentration are recorded in Fig. 3. The rate of uptake of oxygen diminished much more rapidly with $(+)$-catechin

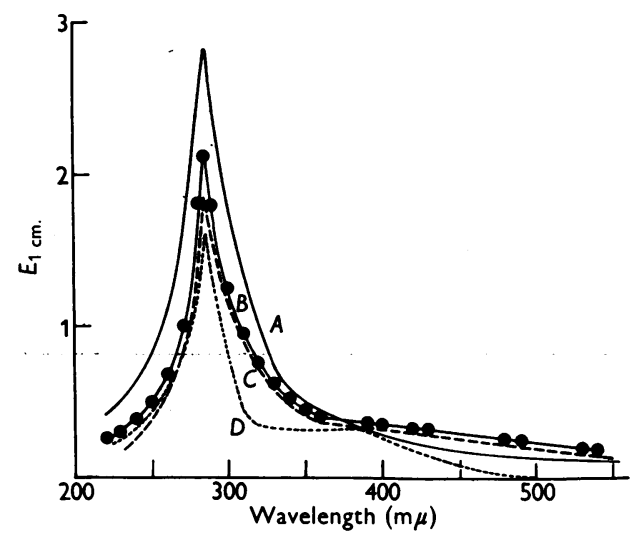

Fig. 4. Absorption spectra of oak-bark phlobatannin (A), and the aerobic oxidation polymers of $(+)$-gallocatechin $(B)$, leucodelphinidin $(C)$ and 5-methylpyrogallol with or without the addition of phloroglucinol or 5-methoxy-4methylresorcinol $(D)$. The spectra were measured in aqueous solution (pH 7). 
and leucodelphinidin than with $(+)$-gallocatechin. Thus the $(+)$-gallocatechin metabolite is oxidized more rapidly than the other metabolites, and units derived from the oxidative polymerization of $(+)$ gallocatechin would therefore be expected to contribute extensively to the structure of oak-bark phlobatannin. The aerobic oxidation of catechin is arrested by the presence of Nakabayashi's (1954) 4-nitrocatechol inhibitor, at the relative concentrations of inhibitor to substrate which he employed. This inhibitor is efficient for catechol and catechin substrates.

The absorption spectrum of oak-bark phlobatannin exhibits a phenolic absorption band at $285 \mathrm{~m} \mu$ and diminishing general absorption in the region 300-600 $\mathrm{m} \mu$. The absorption spectra of $(+)$ gallocatechin and leucodelphinidin-oxidation polymers are also precisely similar to that of oak-bark phlobatannin (Fig. 4).

The aerobic oxidation of an equimolecular mixture of 5-methylpyrogallol and phloroglucinol, and of 5-methylpyrogallol and 5-methoxy-4methylresorcinol, gave polymers which showed a strong absorption band at $285 \mathrm{~m} \mu$ and a shoulder at $350 \mathrm{~m} \mu$, which were identical to those in the spectrum of 5-methylpyrogallol-oxidation polymer alone (Fig. 4).

The analyses on bark detached from different parts of the stem of freshly felled trees show that the concentration of tannin diminishes from ground level to the crown (Table 4).

\section{DISCUSSION}

Examination of the leaves (of Quercus) shows the presence of (+)-catechin, (+)-gallocatechin and several vanillin-positive spots, some of which yield delphinidin on treatment with hot acid and may therefore be concluded to be leucodelphinidins. Besides these compounds some plant pigments, including quercetin, were also present. The occurrence of the $(+)$-catechin, (+)-gallocatechin and leucodelphinidin metabolites in the mature leaves suggests that in the Fagaceae they originate there, and Hillis $(1956 a, b)$ has reached the same conclusion about the origin of the leucoanthocyanins of certain eucalypts (cf. Jaccard, 1938). On account of Davis's (1955) microbial studies and important work involving the use of ${ }^{14} \mathrm{C}$-labelled cinnamic and shikimic acids and L-phenylalanine (Brown \& Neish, 1955; Geissman \& Swain, 1957; Underhill, Watkin \& Neish, 1957; Watkin, Underhill \& Neish, 1957), it is probable that the $(+)$ catechin, (+)-gallocatechin and leucodelphinidin metabolites of Quercus spp. are formed in the leaves by reaction sequences of the sort considered by Neish and his co-workers and Hathway (1956b).

The bark extracts contain the same two catechins (which in this case were isolated in a crystalline state by column chromatography) and several leucoanthocyanins, one of which has also been obtained in a crystalline state and shown to be leucodelphinidin. This is the first time that a crystalline leucoanthocyanin yielding a commonly occurring anthocyanidin has been isolated. In addition to these crystalline compounds, several other low molecular-weight phenols are present, together with a large amount of phlobatannin ('condensed' tannin).

Examination of the cambium showed the presence of a polyphenoloxidase, which acted more readily on the pyrogallol type $[(+)$-gallocatechin and leucodelphinidin] phenols than on the catechol type $[(+)$-catechin $]$ to form polymers.

From earlier work it appears likely that phlobatannin is formed from the oxidation of 'flavans' by polymerization through quinone. An examination of the possible linkage has therefore been made, since for catechin this is head-to-tail (Hathway, 1958; Hathway \& Seakins, 1955; $1957 b$ ). With (+)-gallocatechin and leucodelphinidin as substrates for the cambium oxidase, a polymer is obtained which has a similar ultraviolet spectrum to that of the phlobatannin isolated from the bark, and is in contrast with the results obtained earlier with (+)-catechin and polyphenoloxidases (Hathway \& Seakins, $1957 a$ ). The spectrum obtained is in fact similar to the ultraviolet spectrum of catecholoxidation products (Hathway \& Seakins, 1957b), and suggests strongly that tail-to-tail polymerization occurs. Confirmation of this hypothesis is obtained by the oxidation of 5-methylpyrogallol

Table 4. Distribution of tannin in stembark

\begin{tabular}{|c|c|c|c|c|}
\hline Forest & Date of felling & $\underset{\text { (years) }}{\text { Age }}$ & $\begin{array}{l}\text { Location } \\
\text { on stem }\end{array}$ & $\begin{array}{c}\text { Tannin } \\
\text { percentage on } \\
\text { moisture-free } \\
\text { bark basis }\end{array}$ \\
\hline Goytre & November 1955 & 20 & $\begin{array}{l}\text { Crown } \\
\text { Butt }\end{array}$ & $\begin{array}{l}11 \cdot 5 \\
13 \cdot 5\end{array}$ \\
\hline Chepstow & November 1955 & 20 & $\begin{array}{l}\text { Crown } \\
\text { Butt }\end{array}$ & $\begin{array}{l}11 \cdot 3 \\
13 \cdot 1\end{array}$ \\
\hline Dean & October 1955 & 70 & $\begin{array}{l}\text { Crown } \\
\text { Centre } \\
\text { Butt }\end{array}$ & $\begin{array}{r}7 \cdot 8 \\
10 \cdot 6 \\
11 \cdot 0\end{array}$ \\
\hline
\end{tabular}


with and without added phloroglucinol components. Aerobic oxidation of a mixture of 5-methylpyrogallol and 5-methoxy-4-methylresorcinol, and of 5-methylpyrogallol and phloroglucinol, by polyphenoloxidase, led to polymers which showed the characteristic absorption of the polymers of gallocatechin and catechol oxidation. 3-Hydroxy5-methyl-o-benzoquinone and 5-methoxy-4-methylresorcinol or phloroglucinol do not therefore undergo oxidative coupling. Aerobic oxidation of $(+)$ gallocatechin by oak-cambium polyphenoloxidase proceeds by quinone-polymerization, and affords a product, the tail-to-tail polymer units of which account for the agreement in spectrum of the polymer with those of the catechol polymers including 5-methylpyrogallol polymer (cf. Hathway \& Seakins, 1957a). A partial-type formula is shown in Fig. 5. The phlobatannin and the polymer obtained by the enzymic oxidation of (+)-gallocatechin have the analytical properties of a tannin (Gnamm, 1949; Schmidt, 1955). These polymers are precipitated from solution by gelatin or on refluxing with formalin-hydrochloric acid mixture, and are retained by hide powder (Grassmann, Endisch \& Kuntara, 1951). The reaction of the polymer (and of oak-bark phlobatannin) with vanillin (Procter \& Paessler, 1901) shows that polymerization does not involve the phloroglucinol residue of the monomer.

It is concluded therefore that the pyrogallol phenols are formed in the leaves, translocated to the cambium and undergo oxidation there, and the resulting phlobatannin (which is a tail-to-tail polymer) is stored in the bark. Confirmation of this is obtained in the distribution of 'tannins' in the stembark. The results on the distribution of 'tannins' in oak stembark agree with similar ones relating to the stembark of Betula alba (Jakimoff \& Tolski, 1930), Castanea mollissima (Clarke, Steiner \& Frey, 1942) and Quercus laevis (Rogers, Calderwood \& Beebe, 1950) (Dicotyledonae), and Larix

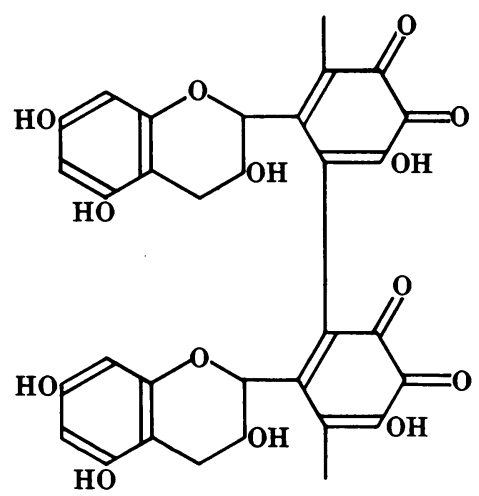

Fig. 5 siberica (Egorov \& Gershenzon, 1939), Pinus echinata (Snow, 1949), P. ponderosa (Kurth \& Hubbard, 1951) and $P$. radiata (Anderson, 1952) (Gymnospermae). Field experiments involving girdled trees are in progress to test this supposition. The presence of phlobatannin in the bark and its absence from the heartwood implies that the cambium does not participate in the formation of heartwood extractives, and there is indirect evidence for this. Anderson (1953) found that the heartwood produced in pines, by stimulation of the cambium, did not contain all the phenols of normal heartwood, and Erdtman (1949) found a lignan in wound heartwood, which was different from that of normal spruce heartwood. The presence of gallocatechin and epigallocatechin in the cacao bean (Forsyth, 1952) and tea leaf (Roberts, 1952) indicates that quinone polymerization accounts for phlobatannins which arise during subsequent fermentation. Low polymers derived from epigallocatechin and epigallocatechin gallate have recently been studied in connexion with tea fermentation (Roberts, 1957), and in agreement with the conclusions drawn from the present work, the evidence favours a tail-to-tail constitution. The isolation of mollisacacidin, $7: 3^{\prime}: 4^{\prime}$-trihydroxyflavan-3:4-diol, from the heartwood (Keppler, 1957), and the detection of this and other leucoanthocyanins in the stembark of Acacia mollissima (Roux, 1957), are of probable significance in relation to the stembark tannins (Hathway \& Seakins, $1957 a$ ). Related 3:4-dihydroxystilbene glycosides have been isolated by countercurrent extraction and column chromatography on nylon from amongst the cambium extractives of spruce (Picea excelsa) (Grassmann, Deffner, Schuster \& Pauckner, 1956; Grassmann, Endres, Brockhaus \& Merkle, 1957 a; Grassman, Endres, Pauckner \& Mathes, $1957 b$ ). Since a polyphenoloxidase has also been found in this tissue (W. Grassmann, personal communication), it is possible that the stembark tannins may be accounted for by the aerobic oxidation through quinone of such dihydroxystilbene aglycones by polyphenoloxidase. The phenolic and phlobatannin extractives of another important tannin material, Eucalpytus redunca heartwood, are now being investigated in this Laboratory. The present conclusion concerning the formation of oak-bark phlobatannins connects the formation of these compounds with the plant-browning reaction (Szent-Györgi \& Vietorisz, 1931).

\section{SUMMARY}

1. (+)-Catechin and (+)-gallocatechin, and leucodelphinidin, were respectively isolated from the ether- and ethyl acetate-soluble fractions of oak-bark phlobatannins. Leucodelphinidin, 
$\mathrm{C}_{15} \mathrm{H}_{14} \mathrm{O}_{8}, \mathrm{H}_{2} \mathrm{O}$, has been characterized by a heptaacetate derivative. $(+)$-Catechin accounts for $1 \%$ of the dry weight of young bark, (+)-gallocatechin for up to $1 \%$ and leucodelphinidin for $0.5 \%$.

2. Oak-bark phlobatannin, $\mathrm{C}_{15} \mathrm{H}_{10} \mathrm{O}_{7}, 2 \mathrm{H}_{2} \mathrm{O}$, was isolated in considerable yield by cellulose-column chromatography, and exhibits an absorption band at $285 \mathrm{~m} \mu$ and diminishing general absorption in the region $300-600 \mathrm{~m} \mu$.

3. Oak cambium exhibits polyphenoloxidase activity which is inhibited by 4-nitrocatechol. (+)-Gallocatechin was oxidized by this enzyme faster than $(+)$-catechin and leucodelphinidin.

4. (+)-Gallocatechin and leucodelphinidin oxidation polymers exhibit the same absorption spectrum, have the same analytical properties and similar elementary analyses to those of oak-bark phlobatannin.

5. Aerobic oxidation of mixed synthetic substrates, such as 5-methylpyrogallol and 5-methoxy4-methylresorcinol, or 5-methylpyrogallol and phloroglucinol, by polyphenoloxidase gave polymers which showed the characteristic absorption of (+)-gallocatechin-oxidation polymer, oak-bark phlobatannin, and 5-methylpyrogallol-oxidation polymer.

6. The conclusion is drawn that phlobatannin is formed by the aerobic oxidation in the cambium of principally $(+)$-gallocatechin through a tail-to-tail quinone-polymerization mechanism.

7. The increase in tannin concentration of oak stembark from crown to butt suggests a downward movement of the phenolic metabolites from the leaves through the phloem.

The author thanks the Director and Council of the British Leather Manufacturers' Research Association for permission to publish this paper, and Mr G. D. Holmes, Silviculturist to the Forestry Commission, of Alice Holt Lodge Research Station, Wrecclesham, Hants, for fresh plant material.

\section{REFERENCES}

Adams, R. \& Levine, I.(1923). J. Amer. chem. Soc. 45, 2373. Anderson, A. B. (1953). Int. Union Pure \& Appl. Chem., Stockholm; Abstr., p. 219.

Anderson, H. (1952). J. Soc. Leath. Tr. Chem. 36, 211.

Bate-Smith, E. C. (1954). Biochem. J. 58, 122.

Bradfield, A. E., Penney, M. \& Wright, W. B. (1947). J. chem. Soc. p. 32.

Brown, S. A. \& Neish, A. C. (1955). Nature, Lond., 175, 688. Burton, H. \& Praill, P. F. G. (1951). J. chem. Soc. p. 522. Casparis, P. \& Reber, K. (1929). Pharm. Acta Helvet.4, 181. Clarke, I. D., Steiner, E. T. \& Frey, R. W. (1942). J. Amer. Leath. Chem. Ass. 37, 591.

Curd, F. H., Robertson, A. \& Stephenson, R. J. (1933). J. chem. Soc. p. 130.

Davis, B. D. (1955). Advanc. Enzymol. 16, 247.

Egorov, B. A. \& Gershenzon, M. L. (1939). Chem. Abstr. 33, 9703.

Erdtman, H. (1949). T.A.P.P.I. 35, 305.

Forsyth, W. G. C. (1952). Biochem. J. 51, 511.
Freudenberg, K. \& Purrmann, L. (1924). Liebigs Ann. 437, 274.

Geissman, T. A. \& Swain, T. (1957). Chem. \& Ind. p. 984.

Gnamm, H. (1949). In Die Gerbstoffe und Gerbmittel, 3rd ed., p. 55. Stuttgart: Wissenschaftliche Verlag.

Grassmann, W., Deffner, G., Schuster, E. \& Pauckner, W. (1956). Ber. dtsch. chem. Ges. 89, 2523.

Grassmann, W., Endisch, O. \& Kuntara, W. (1951). Das Leder, 2, 202.

Grassmann, W., Endres, H., Brockhaus, R. \& Merkle, K. (1957a). Ber. dtsch. chem. Ges. 90, 2416.

Grassmann, W., Endres, H., Pauckner, W. \& Mathes, H. (1957b). Ber. dtsch. chem. Ges. 90, 1125.

Haldane, J. B. S. (1921). J. Path. Bact. 23, 443.

Hathway, D. E. (1956a). Nature, Lond., 177, 747.

Hathway, D. E. (1956b). Biochem. J. 63, 380.

Hathway, D. E. (1958). J. chem. Soc. p. 520.

Hathway, D. E. \& Seakins, J. W. T. (1955). Nature, Lond., 176, 218.

Hathway, D. E. \& Seakins, J. W. T. (1957a). Biochem. J. 67, 239.

Hathway, D. E. \& Seakins, J. W. T. (1957b). J. chem. Soc. p. 1562 .

Hillis, W. E. (1956a). Aust. J. biol. Sci. 9, 263.

Hillis, W. E. (1956b). Symp. Soc. Leath. Tr. Chem.: Vegetable Tannins, p. 121.

Hoesch, K. (1913). Ber. dtsch. chem. Ges. 46, 887.

Howes, F. N. (1953). In Vegetable Tanning Materials, p. 85. London: Butterworths Scientific Publications.

Jaccard, P. (1938). Ber. eidgenöss. Techn. Hochsch. Zurich, no. 36.

Jakimoff, P. \& Tolski, P. (1930). Collegium, Haltingen, $721,233$.

Keilin, D. \& Mann, T. (1938). Proc. Roy. Soc. B, 125, 187.

Keppler, H. H. (1957). J. chem. Soc. p. 2721.

Kurth, E. F. \& Hubbard, J. K. (1951). Industr. Engng Chem. 43, 896.

Mayer, W. (1956). Symp. Soc. Leath. Tr. Chem.: Vegetable Tannins, p. 127.

Nakabayashi, T. (1954). J.agric. chem. Soc. Japan, 28, 212. Official Methods of Analysis (1957), p. 14. Croydon: The Society of Leather Trades' Chemists.

Pfau, A. St (1926). Helv. chim. acta, 9, 650.

Procter, H. R. \& Paessler, J. (1901). In Leitfaden für Gerbereichemische Untersuchungen, p. 78. Berlin: Julius Springer.

Rao, P. R. \& Seshadri, T. R. (1948). J. sci. industr. Res. $7 \mathrm{~B}, 59$.

Roberts, E. A. H. (1952). J. Sci. Fd Agric. 5, 193.

Roberts, E. A. H. (1957). Chem. \& Ind. p. 1355.

Robertson, A. \& Stephenson, R. J. (1932). J. chem. Soc. p. 1393.

Robertson, A.\& Whalley, W. B.(1951). J.chem.Soc. p. 3355.

Rogers, J. S., Calderwood, H. N. \& Beebe, C. W. (1950). J. Amer. Leath. Chem. Ass. 45, 733.

Roux, D. G. (1957). Nature, Lond., 180, 973.

Schmidt, O. T. (1955). In Moderne Methoden der Pflanzenanalyse, vol. 3, p. 515. Ed. by Paech, K. \& Tracey, M. V. Berlin: Springer-Verlag.

Snow, E. A. (1949). J. Amer. Leath. Chem. Ass. 44, 504.

Szent-Györgi, A. \& Vietorisz, K. (1931). Biochem.Z.233, 236.

Underhill, E. W., Watkin, J. E. \& Neish, A. C. (1957). Canad. J. Biochem. Physiol. 35, 219.

Watkin, J. E., Underhill, E. W. \& Neish, A. C. (1957). Canad. J. Biochem. Physiol. 35, 229. 